\title{
THE ESSENCE AND SIGNIFICANCE OF THE STAGE OF INITIATION OF A CRIMINAL CASE
}

\section{Bakhtiyar Botirovich Khidoyatov}

Professor,Department of Criminal Procedure Law,Tashkent State University of Law,Email address: baht_mag @ mail.ru

\begin{abstract}
The article analyzes the problems of the initial stage of criminal proceedings caused by changes in the criminal procedure legislation. Special attention is paid to improving the rules governing the procedure for conducting pre-investigation checks, as well as regulating the stage of initiation of criminal proceedings.
\end{abstract}

Keywords:

Criminal proceeding, pre-trial proceedings, initiation of criminal case, verification of a report of a crime, inquirer, investigator, prosecutor's supervision.

Article Received: 18 October 2020, Revised: 3 November 2020, Accepted: 24 December 2020

\section{Introduction}

An important role in ensuring strict observance of laws is assigned to criminal proceedings, and, in particular, to its initial stage - the initiation of a criminal case, which no investigation can escape. It is the initiation of a criminal case that is the procedural basis for the further development of the entire criminal procedure, and as already mentioned above, the first stage of the movement of the criminal case, the first stage of the criminal process.

The implementation of the purpose of the criminal process begins already within the framework of the first stage of the criminal process - the stage of initiating a criminal case. In order to protect the rights and legitimate interests of the individual, the state and society from crimes, as well as to protect the individual from illegal and unjustified suspicion, accusation, conviction, restriction of his rights and freedoms, a rational organization of work is necessary at the initial stage of the criminal process, its compliance with the law. This largely determines the disclosure of crimes, ensures the inevitability of responsibility and punishment. Nothing is more conducive to the commission of new crimes than impunity for the previous act. Failure to take appropriate measures for every signal of a crime significantly violates the rights of citizens, infringes on the interests of society, undermines the authority of the state creates an impression of the professional incompetence of law enforcement officials. On the other hand, illegal and unjustified initiation of a criminal case is no less dangerous. One cannot but agree with A.F. Koni [1], who believed that "criminal prosecution is too serious a thing not to cause the most careful deliberation; neither the subsequent acquittal by the court, nor even the termination of the case before being brought to trial very often can't obliterate the material and moral harm caused to a person by hasty and unjustified involvement of him in the criminal case". According to A.P. Ryzhakov and I.V. Golovinskaya, the initiation of a criminal case should be understood as a mental decision taken by the investigator (interrogator, etc.) about the presence at his disposal of a legitimate reason and sufficient grounds indicating signs of a specific crime [2]. U.A. Tukhtasheva believes that the initiation of a criminal case is the initial stage of the criminal process, at which the relevant authorities and officials must decide the issue of starting the proceedings, based on the analysis of the reasons and grounds for this provided by the Criminal Procedure Code [3].

Main Part

A.K. Averchenko proposes to understand the "initiation of a criminal case" in three different aspects:

a criminal procedural institution, which is a set of criminal procedural norms governing legal 
relations when receiving, registering, considering and resolving a crime report;

as a separate procedural act, expressed in the issuance by a competent state body or official of a decision that a criminal proceeding begins on the given act;

As the first stage of the criminal process, consisting of actions and relationships that take place when accepting, considering and resolving the primary information about the crime [4].

Sh. Rezepov endows the stage of initiation of a criminal case with the following features:

it has its own time limits;

the content of this stage is the activity of considering a crime report and making an appropriate decision due to the task of this stage;

its purpose is to establish the procedural conditions necessary for the legal and reasonable initiation of a criminal case, that is, to establish the legality of the reason and the sufficiency of the grounds for initiating a criminal case or to establish procedural grounds for refusing to initiate a criminal case;

the tasks of this stage are the reception, registration and resolution of reports of crimes with the simultaneous consolidation of traces of the crime and the adoption of measures aimed at preventing and suppressing the crime;

this stage is also characterized by the circle of subjects of legal relations, namely: the applicant and the interrogator, the body of inquiry, the investigator and the prosecutor, who are obliged to accept, check the message about any committed or impending crime;

In the process of carrying out activities at this stage, legal relations arise, develop and end only between the indicated subjects of this activity, procedural relations between other persons at this stage are not permitted by law [5].

Each stage has its own independent tasks. The importance of the tasks resolved at such a stage of the criminal process as the initiation of a criminal case determines its social and political significance. Timely and legal resolution of the issue of initiating a criminal case reliably protects the rights and legitimate interests of citizens, the interests of the state, public organizations, etc. from criminal encroachments. At the stage of initiating a criminal case, the necessary response of the authorities to each criminal fact is provided. In the activities of prosecutors, investigators, and judicial officials, the resolution of the issue of initiating a case takes an important place in the fight against crimes. Success in solving, preventing and suppressing crimes, in fulfilling the tasks of criminal proceedings, largely depends on how correctly and skillfully the tasks at this stage are resolved.

The independence of the stage of initiation of a criminal case from other stages of the progress of the case is due to the nature of the issues being resolved. In particular, here not only are reports of a committed crime being received, but the information received is verified, and a wellfounded decision is made to initiate a criminal case or refuse it. In this case, a two-pronged task is carried out.

On the one hand, the response to each fact of the commission of a crime, on the other hand, the protection of the subsequent stages of the criminal process, in particular the stage of preliminary investigation, from consideration of the facts:

Which in reality did not exist;

Certainly not criminal, that is, in which there is no at least one of the mandatory signs of the objective side of the corpus delicti, including minor (administrative, disciplinary and other offenses).

At this stage, there are specific criminal procedural relations that differ from those existing at the stage of preliminary investigation. The independent nature of the stage of initiation of a criminal case is also manifested in the fact that it is a stage of criminal procedural activity, and not a single criminal case can arise outside of it. Without the initiation of a criminal case by the authorized bodies in each individual case, there is no legal basis for all those actions that are provided for by law.

So, the initiation of a criminal case is the initial stage of the criminal process, the essence of which is the establishment by the competent authorities of the state of the conditions necessary for the 
proceedings in the criminal case, and in making decisions to initiate a criminal case, to refuse to initiate or to transfer the application received by this body reports on jurisdiction or jurisdiction.

The initiation of a criminal case is a necessary, mandatory part of criminal proceedings. Not a single criminal case can escape this stage of the criminal process. "... Claiming that the initiation of a criminal case is an independent stage of the process, we proceed from the assumption that this initial stage of criminal proceedings has all the features characteristic of the stage of the criminal process. This stage of criminal proceedings has independent tasks. The activity to initiate a case is carried out by competent persons, takes place in certain conditions and in specific procedural forms. This stage ends with a specific decision that determines the further movement of the case" [6].

In the legal literature, the point of view that the initiation of a criminal case is an independent stage of the process is generally recognized. But there are a number of authors expressing the opposite point of view, that is, they do not recognize the initiation of a criminal case as an independent stage and consider it the initial stage of the preliminary investigation $(\mathrm{V}$. Ishchenko, $\mathrm{V}$. Gromov, E.A. Pryanishnikov, etc.)[7]. If you agree with this opinion, then the beginning of the investigation stage should be considered the acceptance of the statement or report of the crime. This removes the prohibition to perform investigative actions before the issuance of an act on the initiation of a criminal case. In addition, the terms of the preliminary investigation in this case will need to be calculated from the moment of receipt of the primary material about the committed offense, and not from the moment of the decision to initiate the case.

Assuming that the thesis about the independence of the stage of initiating a criminal case does not require additional argumentation, it should be noted that in the theory of criminal process the first stage of criminal proceedings is called differently. The most common name is "initiation of a criminal case", although in the legal literature other options are suggested: initiation of criminal proceedings; consideration of reports of crimes; the stage of resolving the issue of initiating a criminal case; the stage of resolving the issue of the need for an investigation; stage of consideration and resolution of reports of crimes. The traditional position seems to be the most justified, since the term "initiation of a criminal case" reflects the main goal set for the inquiry officer, investigator and prosecutor at this stage of the criminal process - to resolve the issue of initiating a criminal case. It is no coincidence that the first stage of the criminal process is called this way in Chapter 41 of the Criminal Procedure Code of the Republic of Uzbekistan.

According to its content, the stage of initiation of a criminal case consists not only in initiating a criminal case or in refusing to initiate a criminal case, but also in procedural activity before a decision is made on an application or message. It examines and resolves a number of issues prior to the issuance of the order. Among them are the following:

is the report about an impending or committed crime a legitimate reason to initiate a criminal case;

Whether the facts about which information was obtained from the crime report contain signs of a crime;

What article of the Criminal Code can a crime be classified under;

On the basis of what specific data it is recognized that the facts about which information was obtained did indeed take place;

should the circumstances of the crime conduct an inspection of the scene;

Whether there is a need for a preliminary check and, if so, what checking actions should be carried out;

Does this body and a specific official have the right to resolve the issue of initiating a criminal case or the available materials are subject to transfer under investigation (Articles 330, 335 of the Criminal Procedure Code of the Republic of Uzbekistan);

have the circumstances been established that prevent the initiation of a criminal case;

are there any grounds for sending materials without initiating a criminal case for taking measures of public influence (inaccordance with 
Article 334 of the Criminal Procedure Code of the Republic of Uzbekistan.);

Who should conduct an inquiry or preliminary investigation in the event of a criminal case; whether the crime is one of those cases about which are initiated only on the basis of the complaint of the victim (Article 325 of the Criminal Procedure Code of the Republic of Uzbekistan) and are subject to termination in the event of his reconciliation with the accused (Article 661 of the Criminal Procedure Code of the Republic of Uzbekistan), what measures in this case can be accepted by a judge for reconciliation);

What measures should be taken to prevent or suppress a crime, as well as to consolidate and preserve traces of a crime.

In connection with the consideration of the above issues, before a decision is made to initiate a criminal case or to refuse to initiate a criminal case, the actions provided for by law are performed and a number of documents are drawn up: a protocol of an oral statement with the applicant's signature warning him about responsibility for knowingly false reporting of a crime; protocol of declaration of guilt; inquiries to enterprises, institutions and organizations, as well as obtaining explanations from citizens during the preliminary check; a resolution on reconciliation or an agreement on this between the victim and the person against whom the complaint was filed; informing the investigator or prosecutor to the body of inquiry about the need to take operational-search measures during the preliminary check; decree on the direction of materials under investigation; scene inspection report.

Thus, at the stage of initiation of a criminal case, a wide range of criminal procedural actions is carried out, a number of procedural documents are issued, generating a system of criminal procedural relations, the subject of which is the applicant about the crime (citizen, enterprise, institution or organization), the body of inquiry, the investigator, the prosecutor or a judge, as well as members of the public, citizens [8].

The initiation of a criminal case, like other independent stages of the process, has its own specific task, which follows from the general tasks of criminal proceedings. This task consists in receiving, considering, and, if necessary, supplementing with the necessary information the primary materials about the crime in order to establish the legality of the reason and the sufficiency of the grounds for initiating a criminal case. At this stage, the circumstances that exclude the proceedings on the case are also subject to clarification, and the task is to prevent or suppress the crime, to fix its traces in a certain procedural form.

N.N. Polyansky notes that "the initiation of a criminal case has its task to establish only the existence of a legal basis for the activity that will face the task of investigating a criminal case" [9]. This stage creates only the necessary conditions for the implementation of tasks and for the identification of the person who committed the crime at the next stage of the process.

If there is a reason to initiate a criminal case, the only task of the stage of initiating a criminal case is to establish the presence or absence of grounds for initiating a criminal case, to establish whether there is sufficient evidence to suggest that in this particular case there was a crime. This stage is not faced with the task of establishing the person who committed the act, his guilt. Such tasks are solved in the stage of inquiry and preliminary investigation following the initiation of a criminal case. Correctly, in our opinion, Yu.K Yakimovich and T.D. Pan note that it is impossible, as it sometimes happens in practice, to turn the stage of initiation of a criminal case into a "rehearsal" of a preliminary investigation [10].

The specificity of the stage of initiation of a criminal case is, first of all, that it takes place outside the framework of proceedings on a specific criminal case. All actions that make up this stage are committed before the criminal case arises and provide a legal and substantiated solution to the issue of starting criminal proceedings.

If the statement or report of a crime lacks sufficient data indicating signs of a crime, the competent authorities face the task of verifying them. Hence, the nature of the actions aimed at verifying the data necessary for making a decision 
to initiate a criminal case is somewhat different than at the stage of inquiry and preliminary investigation. If the main content of the stage of inquiry and preliminary investigation is the production of investigative actions, then at this stage actions are performed that have a different legal nature [11].

An exception is the production of certain procedural and investigative actions. By virtue of part 2 of article $320^{2}$, part 2 of article 329 of the Code of Criminal Procedure of the Republic of Uzbekistan, during a pre-investigation check, a person may be detained, as well as such investigative actions as a personal search and seizure, an inspection of the scene, an examination, and an audit is appointed. In addition, competent persons have the right to issue binding orders to carry out operational-search measures, to demand additional documents and explanations, including from applicants. At the same time, it is in this part that there is a significant procedural gap, since the very uncertain legal status of the persons from whom documents and explanations are requested, as well as the applicants, does not allow them to exercise their rights and legitimate interests in their desired perspective, and the very scope of these rights is insignificant. The importance of the tasks solved at the stage of initiating a criminal case determines its socio-political and legal (legal) significance.

The social and political significance lies in the fact that the legal and timely initiation of a criminal case is a serious means of protecting the violated rights and legitimate interests of citizens and their associations, as well as the state. The stage of initiation of a criminal case is built, like the whole process, on the principles of the criminal process such as legality, respect for the honor and dignity of the individual, protection of the rights and freedoms of citizens, establishing the truth, the presumption of innocence, the obligation to initiate a criminal case, etc., which guarantees against unreasonable and illegal initiation of criminal cases and criminal prosecution of persons; it (the stage of initiation of a criminal case) ensures the response of the authorities to each crime in order to establish the truth and bring the perpetrator to justice, and thereby - the inevitability of punishment for each person who committed the crime. The stage of initiation of a criminal case, like no other, reflects the action of the principle of the obligatory initiation of a criminal case in the criminal process. The essence of this principle is traditionally defined as the duty of the state to protect citizens from criminal encroachments by initiating criminal proceedings upon detection of signs of a crime. Based on this principle, the state, through its bodies, independently decides the issue of starting criminal proceedings, often without taking into account the views of the victims of the crime. The obligatory initiation of criminal cases in a number of cases puts the victims before the need to participate in the criminal process against their will. Not always and not in all cases the possibility and desire of the victims and the accused to settle the case on their own, to settle the contradictions that have arisen as a result of the crime committed by concluding an amicable agreement, is taken into account. According to O.V. Volkolup, there is a dual nature of this principle. On the one hand, its presence excludes lynching and arbitrariness of citizens who have become victims. This principle creates the conditions for the legal and reasonable conduct of the process in the prescribed form, ensuring the achievement of the truth. It creates guarantees of the inevitability of bringing citizens to criminal responsibility. In addition, the presence of this principle allows starting the process when the victim himself is not able, for various reasons, to declare a crime and express his consent to the initiation of the criminal process. On the other hand, the presence of the same principle in the criminal process makes it impossible for the victim to refuse to participate in the case, imposes on him a number of law-restrictive measures, including such as the obligation to appear when summoned to the investigator or to the court, the obligation to give truthful testimony, etc. etc. In this meaning, this principle can not so much ensure the rights and interests of a specific person (victim), but go against them [12].

Equally important is a legal and justified refusal to initiate a criminal case, which often removes from 
citizen undeserved suspicion of committing a crime, prevents investigative and judicial errors, saves investigative, judicial and prosecutorial workers from unnecessary work. In this regard, the facts are especially intolerable when certain officials, if there are sufficient data in the received primary materials indicating signs of a crime, do not take decisions on them provided for by law, and in particular, do not initiate criminal cases, if necessary, and do not refuse to do so. Violation of the law is also the untimely adoption of the necessary decision on a statement or report of a crime.

Failure to initiate or untimely initiation of a criminal case, as a rule, leads to the concealment of crimes, to the loss of evidence, without which it becomes difficult or impossible to establish the truth in the case, as well as to the untimely adoption of measures to search for persons who have committed a crime. Such persons may continue their criminal activities. The rights and legitimate interests of victims of crime are infringed.

Unjustified initiation of a criminal case is also a gross violation of the law. In this case, the honor and dignity of people are undeservedly questioned, the rights and freedoms of citizens are unjustifiably shy many are unjustifiably cut off from their work. Bodies of inquiry and preliminary investigation are wasting time and doing unnecessary work.

The unjustified refusal to initiate a criminal case also causes serious damage to the fight against crime, the protection of the rights and legitimate interests of citizens. This creates an atmosphere of impunity, visible prosperity in the work to combat crime. Unreasonable decisions on refusal to initiate criminal cases are often issued for unsolved crimes.

A violation of the law, giving rise to red tape when deciding on the initiation of a criminal case, is also an unjustified sending of materials about a crime under investigation or jurisdiction [13].

The criminal procedural significance of the stage of initiation of a criminal case lies in the fact that only after the decision to initiate a criminal case has been made in accordance with the procedure established by law, it is allowed to carry out all investigative actions, to apply measures of procedural coercion. The significance of this stage also lies in the fact that it is one of the necessary conditions for both rapid detection of crimes and their full, comprehensive and objective investigation.

Procedural guarantees of the legality and validity of decisions taken at the stage of initiating a criminal case include such provisions as establishing the presence or absence of factual and legal grounds for starting criminal proceedings, ensuring a timely response to crimes for their quick and full disclosure and investigation. Preventing the investigation of facts that do not contain the elements of a crime, the initial determination of the limits of the investigation of the circumstances of a specific criminal case, the establishment of a certain body obliged to carry out proceedings in a criminal case[14].

At the stage of the criminal case, the place of investigation is determined and a personal sign of jurisdiction is established, which is also of great procedural importance (Articles 345 and 346 of the Criminal Procedure Code of the Republic of Uzbekistan) [21].

\section{Conclusion}

The essence of the stage of initiation of a criminal case lies in the fact that the bodies of preliminary investigation take initial information about any committed, committed or planned crime, conduct a comprehensive check of the content of the information, evaluate it and take, guided by the law and their inner conviction, one of the following decisions:

To initiate a criminal case;

To refuse to institute proceedings;

On the transfer of an application or message under investigation.

The Criminal Procedure Law does not contain any indication that a reasoned decision is required when the materials are sent according to jurisdiction. We believe that officials authorized by the criminal procedural law to initiate a criminal case are obliged to make a reasoned decision on the transfer of a statement (report) of a crime by investigation. This follows primarily from the fact that the legislator requires, after receiving information about a crime, as well as 
direct detection of such information, the need for a decision (Article 330 of the CCP). In addition, when sending a statement (message) about a crime under investigation, a competent official is obliged to give reasons for his decision, as well as indicate what measures have been taken to prevent, suppress the crime and fix the traces of the crime [20].

In connection with the above, we propose to amend Article 335 of the Criminal Procedure Code of the Republic of Uzbekistan and give it in the following edition:

Article 335, Submission of a statement (report) on a crime by investigation:

The transmission of a statement (message) by investigation is permissible only in cases when a crime committed outside a given region (city) is reported, and verification actions are required in the region (city) where the crime was committed to resolve the issue of initiating a criminal case. An inquiry officer, investigator, prosecutor shall issue a resolution on the transfer of a statement (message) of a crime by investigation [22].

Another issue that requires its resolution is the time frame for the transmission of a report on a crime under investigation. By virtue of the norm of Article 330 of the Criminal Procedure Code of the Republic of Uzbekistan, in this case, a quite valid question arises, from what moment should the period of consideration of a crime report transferred under investigation be calculated. This gap often becomes the reason for exceeding the deadline for resolving incoming information about committed or impending crimes and requires legislative revision [15].

The initiation of a criminal case also has criminal law significance. In criminal cases, prior to the issuance of a decision on bringing a person to participate in a criminal case as a suspect or accused, there is no other document other than a decision to initiate a criminal case, which would set out the circumstances of a socially dangerous act and give a qualification of a crime [19].

It is the procedural act on the initiation of the case that determines, albeit preliminary, what crime has been committed and is subject to investigation, which gives direction to the proceedings on the case at the first stages of the investigation and at the same time determines the subject (generic) jurisdiction. With the adoption of the decision to initiate a criminal case, for the first time in the criminal process, the norms of criminal law are applied, and, according to A.L. Rivlin [16], it is from the moment of application of the norm of substantive criminal law that criminallegal relations arise and are implemented.The first stage of the implementation of these relations, emphasizes V.Ya. Chekanov [17] is a decision to initiate a criminal case. The data obtained during the initiation of a criminal case often determine the circle, sequence and tactics of the production of urgent investigative actions. The implementation of tasks at the stage of initiating a criminal case is achieved by performing certain procedural actions, accompanied by the emergence and development of criminal procedural relations between persons who are participants in this stage of criminal proceedings[18].

\section{References}

[1] Koni A.F. Selected works. Volume 1. Moscow:1959, -p. 19.

[2] Golovinskaya I.V. Practical problems of initiating criminal cases. // "Russian Investigator”, 2007, No. 10, -p.-3.

[3] Tukhtasheva U.A. Criminal Procedure: General Part. Tutorial, $\mathrm{T}$.: Publishing house of TSUI, 2007.-p. 8.

[4] Averchenko A.K. "Criminal Procedure: Lectures”, 2000. -pp. 98-99.

[5] Rezepov I. Sh. A short course on criminal procedure law: a tutorial, Moscow: 2007. pp. 91-92.

[6] Mikhailenko A.R. Initiation of a criminal case in the Soviet criminal process. Saratov, 1975, -p. 5.

[7] Ishchenko V. A brief practical guide for people's investigators. Moscow: 1925 -pp. 7-8., Gromov V. Preliminary investigation of criminal cases. Moscow:1930, -pp.-121124., Pryashnikov E.A. Some questions of the preliminary investigation. Abstract of 
Candidate's Dissertation. Moscow: 1955, p. 7.

[8] Criminal procedure of the Republic of Uzbekistan: Textbook / Mirensky B.A., Rakhmankulov A.Kh., Kadyrova V.V., Kamalhodjaev D. Tashkent: Academy of the Ministry of Internal Affairs of the Republic of Uzbekistan, 2004. - pp. 244245

[9] Polyansky N.N. Essay on the development of the science of criminal procedure. M., 1960, -p.14

[10] Yakimovich Yu.K., Pan T.D. Pre-trial proceedings under the Code of Criminal Procedure of the Russian Federation. Sat, 2003. - p. 96.

[11] Teterkin B.S., Troshkin E.Z. Initiation and investigation of criminal cases. - Moscow: 1997. -p. 6.

[12] Volkolup O.V. The system of criminal justice and problems of its improvement. $\mathrm{SPb}$.: Publishing house "Legal Center Press", 2003.- p.73.

[13] Mikhailenko A.R. Initiation of a criminal case in the Soviet criminal process. Saratov, 1975, -p. 7-9.

[14] Gromov N.A. Criminal Procedure in Russia: Textbook. Moscow:Jurist, 1998 -p. 92.

[15] Khudaibergenov B.K.Some issues of the stage of initiation of a criminal case in the criminal process // Domestic jurisprudence. - 2020. - No. 1 (40).

[16] Rivlin A. Subekti criminal law vidnosin. "Radyanske Pravo", 1971, No. 3, -pp. 68.
[17] Chekanov V.Ya. Prosecutor's supervision in criminal proceedings. Saratov, 1972, -p. 31.

[18] Mikhailenko A.R. Initiation of a criminal case in the Soviet criminal process. Saratov, 1975, -pp. 910.

[19] Kadirova M., Abdullaev R., Khujanazarov A., Rahimkulova L. Evaluation of the results of judicial computer and technical expertises by the investigators and the court.

DOI: 10.37200/IJPR/V24I6/PR260256.

https://www.psychosocial.com/article/PR26 0256/13667/

[20] Eldarovna, G. N., Ochilov, K., \& Sobirov, B. (2019). Problems of transplantation of human organs and tissues: international standards and international experience. Religación. Revista de Ciencias Sociales y Humanidades, 4(16), 714-719.

[21] Ochilov, X., \& Kamalova, D. (2020). Criminal responsibility for inchoate offence according criminal code of the Republic of Uzbekistan. International Journal of Advanced Science and Technology, 29(5), 1729-1737.

[22] Kurbanov Marufjon Mamadaminovich. SOCIAL NEED TO DETERMINE LIABILITY FOR CRIMES RELATED WITH OBSTRUCTION, ILLEGAL INTERFERENCE IN BUSINESS ACTIVITY. Journal of Law Research. 2020, special issue 3, pp. 197-208. http://dx.doi.org/10.26739/2181-91302020-SI-3-24. 